\title{
Antifungal Activities of Some Leaf Extracts on Seed-borne Fungi of African Yam Bean Seeds, Seed Germination and Seedling Emergence
}

\author{
*NWACHUKWU, E. $O$; UMECHURUBA,C.I. \\ Department of Plant Science and Biotechnology, Faculty of Science, University of Port Harcourt, Port Harcourt. Nigeria.
}

\begin{abstract}
The efficacy of leaf extracts of basil (Ocimum basilicum), bitter leaf (Vernonia amygdalina), lemon grass (Cymbopogen citratus), neem (Azadirachta indica) and paw-paw (Carica papaya) on major seed-borne fungi: Aspergillus niger, Aspergillus flavus, Botryodiplodia theobromae and Fusarium moniliforme of African yam bean ( Sphenostylis stenocarpa) seeds, and on seed germination and seedling emergence were studied in vitro and in vivo. All the plants leaf extracts (crude and aqueous) significantly $(\mathrm{P} \leq 0.05)$ reduced the incidence of seed-borne fungi tested and increased seed germination and seedling emergence except lemon grass leaf extract when compared with the untreated control. Neem extract was the most effective while lemon grass extract was the least. Crude extracts from all the plant leaves tested increased seed germination and seedling emergence of African yam bean seeds and gave significant $(\mathrm{P} \leq 0.05)$ reduction of mycelial growth of all the fungi tested when compared with their aqueous extracts. Leaf extracts of neem, basil, bitter leaf and paw-paw, which are cheap and environmentally safe, are promising for protecting African yam bean seeds against major seed-borne fungi and in the improvement of the crop. @ JASEM
\end{abstract}

African yam bean, Sphenostylis stenocarpa (Hochst ex. Rich) Harms is an important grain legume in most tropical African countries such as Nigeria, Ivory Coast, Ghana, Togo, Gabon, Congo, Ethiopia and some parts of East Africa where it is used as food. The crop also helps agriculturally to enrich the soil by its ability to fix nitrogen from the atmosphere.

A survey of the seed-borne fungi associated with this crop grown in Eastern Nigeria revealed high percentage incidence of Aspergillus niger, Aspergillus flavus, Fusarium moniliforme and Botryodiplodia theobromae (Nwachukwu and Umechuruba, 1991). Umechuruba and Nwachukwu (1994) also reported significant reduction in seed germination, seedling emergence and low seed and tuber yield of African yam bean caused by these important seed-borne fungi, as well as reduction in nutritional qualities of the seeds (Umechuruba and Nwachukwu 1997).

It is therefore necessary to search for control measures that are cheap, ecologically sound and environmentally safe to eliminate or reduce the incidence of these economic important pathogens, so as to increase seed germination and yield of African yam bean.

In recent years much attention has been given to nonchemical systems for seed treatment to protect them against seed-borne pathogens. Plant extracts have played significant role in the inhibition of seed-borne pathogens and in the improvement of seed quality and field emergence of plant seeds. Shah et al, (1992), reported that Argemone mexicana seed extract was effective in eliminating most of the seed-borne fungi of cowpea but not against Alternaria alternata, Curvularia lunata, Mucor sp. and Macrophomina phaseolina. Leaf extracts of Delonix regia, Pongamia glabra and Acacia nilotica significantly inhibited

\footnotetext{
*Corresponding author
}

spore germination, mycelial growth and spore production of A.. helianthi, $M$. phaseolina and $F$. solani from sunflower seeds (Thiribhuvanamala and Narasimhan, 1998). Parimelazhagan and Francis, (1999), in their own studies, reported reduction in the radial growth of $C$. lunata associated with rice seeds when treated with leaf extracts of Clerodendrum viscosum which also increased seed germination and root and shoot lengths of rice.

In this study, the effects of leaf extracts of neem (Azadirachta indica), basil (Ocimum basilicum), bitter leaf (Vernonia amygdalina), pawpaw (Carica papaya) and lemon grass (Cymbopogen citratus) on major seed borne fungi of African yam bean seeds; and on seed germination and seedling emergence were investigated.

\section{MATERIALS AND METHODS}

Extraction of leaf extracts: The fresh leaves of neem, basil, bitter leaf, paw- paw and lemon grass were carefully washed each alone under tap water and cut into tiny pieces. Aqueous extract was prepared as follows: $1 \mathrm{~kg}$ whole leaves of each plant was blended separately in one litre of distilled water in a waring blender and sieved through a Buchner funnel to remove debris. Similarly the crude extract was prepared by blending $1 \mathrm{~kg}$ of each of the plant leaves without water. The extract was sieved through a Buchner funnel also to remove debris.

\section{In vitro tests:}

The seed-borne fungi (Aspergillus niger, A. flavus, $F$. moniliforme and $B$. theobromae) used for this investigation were isolated from naturally infected African yam bean seeds. The in vitro tests were carried out to measure the effects of the leaf extracts 
on radial growth of the seed-borne fungi. Potato dextrose agar (PDA ) medium was used in the study. To every $15 \mathrm{ml}$ of sterile potato dextrose agar medium in Petri dishes, $5 \mathrm{ml}$ of either crude or aqueous extract of each plant were added. The solution in each Petri dish was gently swirled and allowed to solidify. The extract-amended medium in the Petri dishes were inoculated each alone at the centre with $5 \mathrm{~mm}$ inoculum-disc of each test fungus and incubated at 25 $\pm 2{ }^{\circ} \mathrm{C}$ for 14 days. The medium with inoculum disc but without any extract served as control. Percentage inhibition of mycelial growth by the leaf extracts was calculated using the formula:

$$
\% M G_{I}=\frac{D_{C}-D_{T}}{D_{C}} \times 100
$$

Where: $\% \mathrm{MG}_{\mathrm{I}}=\%$ Inhibition of mycelial growth

$$
\mathrm{D}_{\mathrm{C}}=\text { diameter of control }
$$$$
\mathrm{D}_{\mathrm{T}}=\text { diameter of test }
$$

In vivo tests: African yam bean seeds naturally infected with A. niger, A. flavus, F. moniliforme and $B$. theobromae were used for the in vivo tests. The efficacy of the leaf extracts was tested using the blotter method and soil mix in buckets. Seeds were treated with the same crude and aqueous extracts of the plant leaves as previously described. The seeds were soaked in the crude and aqueous leaf extracts separately for one hour and then plated on moist blotters as well as in sterilised soil mix in buckets. The untreated seeds were soaked in distilled water for one hour and plated on moist blotters and sterilised soil mix as control. A total of 400 seeds were soaked per extract (crude or aqueous) and 10 seeds plated on blotter per Petri dish. The extract- treated and untreated seeds were incubated in an incubator at $20 \pm$ $2{ }^{\circ} \mathrm{C}$ for seven days. Seeds plated in blotter were examined for fungal growth and percentage seed germination after 7 days of incubation while percentage seedling emergence was recorded in seeds sown in sterilized soil mix after 14 days. For soil method, 20 seeds were planted per bucket equidistantly at the depth of $2.0 \mathrm{~cm}$ and 5 buckets were used per extract treatments.

\section{RESULTS}

In vitro tests: The effects of the various plant leaf extracts on mycelial growth of major seed-borne fungi of African yam bean seeds are presented in Table 1 . All the leaf extracts significantly $(\mathrm{P} \leq 0.05)$ inhibited the radial mycelial growth of the fungi (Table 1). The percentage inhibition of mycelial growth of the fungi varied with the type of leaf extracts, extract concentration, as well as the type of fungus. Neem leaf extract gave the highest inhibition while the lemon grass extract gave the lowest inhibition. The crude leaf extracts of all the plants significantly $(\mathrm{P} \leq 0.05)$ inhibited growth of all the fungi more than their aqueous extracts (Table1). All the leaf extracts (crude and aqueous) gave highest percentage inhibition of $A$. flavus when compared with the results of other fungi. The control did not inhibit mycelial growth of all the fungi (Table 1).

Table 1. Mean percentage inhibition of mycelial growth of seed- borne fungi by various leaf extracts.

\begin{tabular}{llllll}
\hline Name of plant & Extract & \multicolumn{2}{l}{ Seed borne fungi } & & Af \\
& Conc. & *Fm & Bt & An & Af.5h \\
\hline Azadirachta indica & Crude & $68.0 \mathrm{~g}$ & $78.5 \mathrm{~h}$ & $88.3 \mathrm{~h}$ & $91.5 \mathrm{~h}$ \\
(Neem) & Aqueous & $56.0 \mathrm{f}$ & $53.3 \mathrm{f}$ & $70.1 \mathrm{f}$ & $80.5 \mathrm{f}$ \\
Vernonia amygdalina & Crude & $55.3 \mathrm{~F}$ & 68.29 & $76.1 \mathrm{~g}$ & $88.3 \mathrm{~g}$ \\
(Bitter leaf ) & Aqueous & $30.5 \mathrm{~d}$ & $49.0 \mathrm{e}$ & $61.5 \mathrm{e}$ & $70.0 \mathrm{e}$ \\
Ocimum basilicum & Crude & $44.0 \mathrm{e}$ & $50.5 \mathrm{e}$ & $62.0 \mathrm{e}$ & $71.0 \mathrm{e}$ \\
( Basil ) & Aqueous & $28.3 \mathrm{~d}$ & $37.6 \mathrm{~d}$ & $50.3 \mathrm{~d}$ & $61.8 \mathrm{~d}$ \\
Carica papaya & Crude & $48.7 \mathrm{e}$ & $55.3 \mathrm{f}$ & $70.0 \mathrm{f}$ & $78.0 \mathrm{f}$ \\
( Paw-paw ) & Aqueous & $32.1 \mathrm{~d}$ & $39.8 \mathrm{~g}$ & $60.3 \mathrm{e}$ & $60.3 \mathrm{~d}$ \\
Cymbopogen citratus & Crude & $14.5 \mathrm{~b}$ & $24.5 \mathrm{c}$ & $30.5 \mathrm{c}$ & $36.7 \mathrm{c}$ \\
( Lemon grass ) & Aqueous & $10.3 \mathrm{~b}$ & $15.0 \mathrm{~b}$ & $19.7 \mathrm{~b}$ & $21.8 \mathrm{~b}$ \\
Control & Distilled water & $0.0 \mathrm{a}$ & $0.0 \mathrm{a}$ & $0.0 \mathrm{a}$ & $0.0 \mathrm{a}$
\end{tabular}

Mean of 6 replicates. Means followed by the same letter(s) do not differ significantly at 5\% (DMRT) ${ }^{*} \mathrm{Fm}=$ Fusarium moniliforme, $\mathrm{Bt}=$ Botryodiplodia theobromae, An = Aspergillus niger, Af $=$ Aspergillus flavus

In vivo test:

The effects of the plants' leaves extracts on the incidence of seed-borne fungi, seed germination and seedling emergence are presented in Table 2. All the leaf extracts (crude and aqueous) significantly ( $\mathrm{P} \leq$ 0.05 ) reduced the incidence of all the seed-borne fungi, increased seed germination and seedling emergence except leaf extract from lemon grass 
which was ineffective when compared with the untreated control seeds (Table 2).

The crude leaf extracts of all the plants were more effective than the aqueous leaf extracts in reducing seed-borne fungi and in increasing seed germination and seedling emergence. The extract from neem leaf was the most effective in the reduction of seed-borne fungi and increase in seed germination and seedling emergence(Table 2). The crude leaf extract of this plant also gave complete control of $A$. niger and $A$. flavus (Table 2). Seed germination and seedling emergence were higher in seeds treated with leaf extracts of neem $(89.0 \%$ and $81.3 \%)$ respectively followed by leaf extracts of bitterleaf $(82.5 \%$ and $75.0 \%)$, paw-paw (80.1\% and 68.8\%) and basil (66.0\% and $56.8 \%$ ) respectively. The extracts from lemon grass did not reduce the incidence of seedborne fungi. Also seed germination was not enhanced by this extract.

Table 2. Effect of different leaf extracts on the incidence of seed- borne fungi, seed germination and seedling emergence of African yam bean seeds.

\begin{tabular}{|c|c|c|c|c|c|c|c|}
\hline \multirow{2}{*}{ Name of plant } & \multirow{2}{*}{$\begin{array}{l}\text { Extract } \\
\text { Conc. }\end{array}$} & \multicolumn{4}{|c|}{ Mean \% seed- borne fungi } & \multirow[t]{2}{*}{$\begin{array}{l}\text { Mean \% seed } \\
\text { germination }\end{array}$} & \multirow{2}{*}{$\begin{array}{l}\text { Mean \% } \\
\text { seedling } \\
\text { emergen } \\
\text { ce }\end{array}$} \\
\hline & & $* \mathrm{Fm}$ & An & Af & & & \\
\hline A.. indica & Crude & $5.3 a$ & $4.0 \mathrm{a}$ & $0.0 \mathrm{a}$ & $0.0 \mathrm{a}$ & $89.0 \mathrm{~g}$ & $81.3 g$ \\
\hline (Neem) & Aqueous & $8.8 \mathrm{~b}$ & $0.0 \mathrm{a}$ & $5.3 b$ & $4.0 \mathrm{~b}$ & $75.0 \mathrm{e}$ & 69.5de \\
\hline V. amygdalina & Crude & $20.5 a$ & $18.4 \mathrm{a}$ & $16.5 d$ & $15.3 a$ & $82.5 \mathrm{e}$ & $75.0 f$ \\
\hline (Bitter leaf ) & Aqueous & 3o.1c & $24.8 \mathrm{~b}$ & $25.0 \mathrm{~b}$ & $20.5 b$ & $61.3 c$ & $60.0 \mathrm{c}$ \\
\hline O. bacilicum & Crude & $28.0 \mathrm{~b}$ & $22.0 \mathrm{a}$ & $24.2 b$ & $22.0 \mathrm{~b}$ & $66.0 \mathrm{~d}$ & $60.1 c$ \\
\hline (Basil) & Aqueous & 34.3cd & $26.8 b$ & $28.3 c$ & $28.3 c$ & $56.8 b$ & $53.5 b$ \\
\hline C. papaya & Crude & $29.3 b$ & $20.3 a$ & $28.0 \mathrm{c}$ & $21.5 b$ & $80.1 \mathrm{e}$ & $70.5 \mathrm{e}$ \\
\hline ( Paw- paw ) & Aqueous & $32.5 c$ & $27.0 \mathrm{bc}$ & $35.0 \mathrm{~d}$ & $30.1 d$ & $68.8 \mathrm{~d}$ & $67.0 \mathrm{~d}$ \\
\hline C. citratus & Crude & $39.5 d$ & $28.2 \mathrm{c}$ & $55.5 e$ & $60.0 \mathrm{e}$ & $50.0 \mathrm{a}$ & $46.3 a$ \\
\hline ( Lemon grass ) & Aqueous & 41.3e & 30.3d & $60.0 f$ & $66.8 f$ & $53.3 a$ & $48.5 a$ \\
\hline Untreated control & $\begin{array}{l}\text { Distilled } \\
\text { water }\end{array}$ & $42.5 \mathrm{e}$ & 31.0d & $62.8 \mathrm{f}$ & $68.5 f$ & $55.0 \mathrm{a}$ & $48.0 \mathrm{a}$ \\
\hline
\end{tabular}

*Fm= Fusarium moniliforme, $\mathrm{Bt}=$ Botryodiplodia theobromae $\mathrm{An}=$ Aspergillus niger and Af = Aspergillus flavus

Figures followed by different letters in columns differ significantly when subjected to $\operatorname{DMRT}(\mathrm{P} \leq 0.05)$.

\section{DISCUSSIONS}

The efficacy of different plant leaf extracts (neem, basil, pawpaw, bitter leaf and lemon grass) against major seed borne fungi of African yam bean seeds was tested in vitro and in vivo. The results showed that the five plant leaf extracts significantly $(\mathrm{P} \leq 0.05)$ inhibited the radial growth of all the test fungi with inhibition varying from one extract to another (Table 1). Percentage inhibition of radial growth of all the fungi was highest in neem extract and lowest in extract from lemon grass (Table 1). Parimelazhagan and Francis (1999), reported a significant reduction of radial growth and mycelial dry weight of $C$. lunata in extract of Clerodendrum viscosum. Nidiry (1999), also obtained a similar result with tomato seed extract, which reduced the mycelial growth of Colletotrichum gloeosporioides and spore germination of Cladosporum cucumerinum.
All the leaf extracts were effective in the reduction of the incidence of all the seed borne fungi tested except extracts from lemon grass that did not give significant $(\mathrm{P} \leq 0.05)$ reduction of the fungi when compared with untreated control seeds (Table 2). This result indicates that the leaf extracts of neem, paw paw, basil and bitter leaf probably have some fungicidal properties that inhibit the growth of the seed borne fungi. The crude extracts were more effective in reducing the incidence of fungi than the aqueous extracts. This is an indication that dilution of the extracts reduced toxic effects of the leaf extracts on the seed-borne fungi. This result agrees with the findings of Zaman et al (1997), that the efficacy of garlic, neem, ginger and onion extracts on seed borne fungi of mustard declined with increase dilution.

The extracts were not phytotoxic to African yam bean seeds rather they improved seed germination and 
seedling emergence significantly $(\mathrm{P} \leq 0.05)$ more than the untreated control seeds (Table 2). The extracts from lemon grass were ineffective in improving seed germination and seedling emergence (Table 2).

The ability of the extracts to increase seed germination and seedling emergence could be attributed to the suppression of the incidence of the seed borne fungi that could have killed the embryo of the seeds. This result is consistent with that of Parimelazhagan and Francis, (1999) who established that leaf extracts of $C$. viscosum increased seed germination and improved seedling development of rice seeds.

This present study has therefore shown that leaf extracts of neem, paw-paw, basil and bitter leaf can be used as fungicidal seed treatments for the control of seed-borne fungi of African yam bean seeds and for increasing seed germination and seedling emergence.

\section{REFERENCES}

Nidiry, E. S. J. (1999). Antifungal activity of tomato seed extracts.Fitoterapia, 70 (2):181-183.

Nwachukwu, E.O. and Umechuruba, C.I. (1991). Seed-borne fungi associated with African yam bean

seeds in four Eastern States of Nigeria. Seed Research, 19 (1): 13-20.

Nwachukwu, E.O. and Umechuruba, C. I. (1997). Changes in nutritional values of African yam beanseeds due to seed- borne fungi. Global Journal of Pure and Applied Sciences, 3 (2):141-147.

Parimelazhagan, T. and Francis, K. (1999). Antifungal activity of Clerodendrum viscosum against Curvularia lunata in riceseeds. Journal of Mycology and Plant Pathology 29 (1): 139- 141.

Shah, N.H., Khan, M.I.and Azam, M.F. (1992). Seed microflora of cowpea and its control with extract of Argemone mexicana.Bioved 3 (2): 176-168.

Thiribhuvanamala, G. and Narasimhan, V. (1998). Efficacy of plant extracts on seed- borne pathogens of sunflower . Madras Agricultural Journal, 85 (5/6): 227-230.

Umechuruba, C.I. and Nwachukwu, E.O. (1994). Efficacy of certain fungicides against seedborne

fungi of African yam bean seeds. International Journal of Pest Management, 4 (2): 126-131.

Zaman,M.A, Saleh, A.K.M., Rahman, G.M.M, and Islam, M.T. (1997). Seed-borne fungi of mustard

and their control with indigenous plant extracts. Bangladesh Journal Plant Pathology, 13 (1/2): 25-28. 